\title{
EVALUASI PELAKSANAAN GOOD MANUFACTURING PRACTICES (GMP) DAN ANALISIS EFISIENSI BIAYA DI PUSAT PENGOLAHAN KAKAO RAKYAT JEMBRANA BALI
}

\author{
Tidar Aden Hawa \\ Jurusan Agribisnis Fakultas Pertanian Universitas Islam Jember \\ Email: tidaraden29@gmail.com
}

\begin{abstract}
Although the amount of Indonesian cocoa production is quite high, but the volume of cocoa grinding is still relatively low compared to the potential that should be obtained. Therefore, Indonesia should improve the cocoa processing industry sector. This research was intended to: analyze the implementation of each component of Good Manufacturing Practices (GMP) at Smallholder Cocoa Processing Center (PPKR) of Jembrana in accordance with Agriculture Minister's Regulation No. 35/Permentan/OT.140/7/2008; analyze the efficiency level of the use of costs at PPKR Jembrana. The research results showed that the level of GMP implementation based on Agriculture Minister's Regulation No.35/Permentan/OT.140/7/2008 at PPKR Jembrana was still partial (47\%). In the one year production, the use of costs at PPKR Jembrana was efficient indicated by the value of $R / C>1$, but the value was resulted by subsidized cost structure (cost of raw materials/cocoa seeds, employee salaries, depreciation of equipment, machinery depreciation, building depreciation, property and building taxes, electricity cost, and water cost). If subsidies were removed, the value of efficiency would drop even become inefficient. By the whole implementation of GMP, the inefficient costs in form of process failure cost and product return cost can be reduced, so the efficiency of the costs use will increase.
\end{abstract}

Keywords: Cocoa, GMP, R/C ratio, Smallholder Cocoa Processing Center (PPKR) of Jembrana

\section{PENDAHULUAN}

Kakao merupakan salah satu komoditas andalan perkebunan yang peranannya cukup penting bagi perekonomian nasional. Dalam kancah pasar dunia, keberadaan Indonesia sebagai produsen kakao utama di dunia cukup diperhitungkan dan berpeluang untuk menguasai pasar global. Berdasarkan data ICCO (International Cocoa Organization) tahun 2014/2015, Indonesia memiliki kontribusi sebagai pemasok utama kakao dunia. Produksi kakao Indonesia menempati urutan terbesar ke-3 dunia $(7,64 \%$ dari 4.251.000 ton produksi kakao dunia) setelah Pantai Gading (42,25\%) dan Ghana (17,41\%) (ICCO, 2016). Permintaan pasar terhadap produk kakao tidak hanya dalam bentuk biji fermentasi, namun juga permintaan dalam bentuk olahan. Setiap tahun permintaan hasil kakao olahan Indonesia mengalami trend yang meningkat untuk memenuhi kebutuhan konsumsi industri makanan dan minuman di pasar domestik maupun pasar internasional (Rahmanu, 2009).
Meskipun jumlah produksi kakao Indonesia cukup tinggi, akan tetapi volume grinding (pengolahan/konsumsi) kakaonya masih relatif rendah dibanding potensi yang seharusnya diperoleh. Volume grinding menunjukkan volume biji kakao yang diolah oleh industri menjadi produk olahan kakao (pasta, lemak, bungkil, dan bubuk kakao).

Perkembangan industri pengolahan kakao cenderung lebih lambat jika dibandingkan dengan perkembangan usahatani kakao yang mengindikasikan bahwa industri hilir kakao belum berkembang dengan baik (Hasibuan, 2012). Hal ini dikarenakan selama ini Indonesia lebih banyak mengekspor kakao dalam bentuk bean sedangkan peluang industri pengolahan kakao kurang optimal dimanfaatkan, padahal industri produk olahan kakao memiliki nilai tambah dan penyerapan tenaga kerja yang cukup besar (Asheri, 2014).

Produksi kakao yang terus meningkat, potensi pasar yang besar, dan melimpahnya bahan baku serta ketersediaan tenaga kerja yang relatif 
banyak jumlahnya merupakan modal besar bagi pengembangan industri berbasis kakao di Indonesia. Dengan demikian seharusnya Indonesia memperbaiki sektor industri pengolahan kakao, utamanya yang berbasis kerakyatan.

Kabupaten Jembrana merupakan salah satu daerah pusat pengolahan kakao rakyat di Bali. Didirikannya Pusat Pengolahan Kakao Rakyat Jembrana (PPKR Jembrana) merupakan dukungan kuat pemerintah daerah terhadap lingkungan agribisnis kakao. Namun saat ini pemasaran produk skunder kakao yang dihasilkan oleh PPKR Jembrana masih terbatas pada pasar lokal dengan mutu dan harga yang relatif kurang bersaing. Industri pengolahan kakao ini perlu lebih berorientasi pada pelanggan dengan mutu dan harga yang sesuai, karena pada dasarnya PPKR Jembrana berpotensi untuk memperluas skala usahanya hingga nasional. Menurut Burhanuddin (2002), untuk mengantisipasi persaingan, aspek mutu perlu selalu dievaluasi dan direncanakan perbaikannya melalui penerapan manajemen mutu. Diperlukan jaminan bahwa produk yang memasuki proses produksi benar-benar akan memuaskan kebutuhan para konsumen, sehingga produsen dapat menggunakan biaya secara lebih efisien.

Berkaitan dengan penerapan manajemen mutu proses, diperlukan analisis tingkat pelaksanaan komponen-komponen Good Manufacturing Practices (GMP) menurut ketentuan yang ditetapkan (Peraturan Menteri Pertanian Nomor : 35/Permentan/Ot.140/7/2008 tentang persyaratan dan penerapan Cara Pengolahan Hasil Pertanian Asal Tumbuhan Yang Baik). Analisis efisiensi diperlukan untuk mengevaluasi pelaksanaan GMP di PPKR Jembrana agar di kemudian hari penggunaan biaya menjadi lebih efisien.

\section{METODE PENELITIAN}

Teknik pengumpulan data dilakukan dengan cara pengamatan (observasi) langsung di lapang dan wawancara. Metode analisis yang digunakan adalah deskriptif analitik. Data observasi pelaksanaan GMP di PPKR Jembrana dibandingkan dengan Persyaratan dan Penerapan GMP Permentan No. 35/Permentan/OT.140-/7/2008, untuk kemudian dipersentase dan diskorkan. Rumus untuk menghitung tingkat pelaksanaan GMP di setiap komponen adalah:

$\%$ pelaksanaan $=$ rerata pelaksanaan sub komponen dalam satu komponen
Pelaksanaaan GMP dibagi dalam 5 kategori skor. Pelaksanaan GMP dikatakan rendah jika persentase pelaksanaan antara $0 \%$ hingga $20 \%$; agak rendah jika persentase $20,01 \%$ hingga $40,00 \%$; sebagian jika persentase 40,01\%-60,00\%; agak tinggi jika persentase $60,01 \%$ hingga $80,00 \%$; dan pelaksanaan GMP dikategorikan tinggi jika persentase pelaksanaan GMP 80,01\%-100,00\%.

Efisiensi biaya produksi di PPKR Jembrana menggunakan pendekatan $\mathrm{R} / \mathrm{C}$ ratio (Soekartawi, 1995). R/C ratiodiformulasikan sebagai berikut:

$$
R / \text { C ratio }=\frac{\text { Total Penerimaan }(R p)}{\text { Total Biava }(R p)}
$$

\section{Kriteria:}
a. $\mathrm{R} / \mathrm{C}$ ratio $>1$, maka penggunaan biaya produksi di PPKR Jembrana efisien.
b. $\mathrm{R} / \mathrm{C}$ ratio $\leq 1$, maka penggunaan biaya $\mathrm{di}$ PPKR Jembrana tidak efisien.

\section{HASIL DAN PEMBAHASAN}

Jaminan mutu dan keamanan pangan merupakan salah satu faktor penentu daya saing produk pangan baik di pasar domestik maupun di pasar internasional. Dukungan berupa kebijakan tentang jaminan mutu dan keamanan pangan telah terbentuk seperti Permentan No.58/Permen$\tan /$ OT.140/8/2007 tentang Sistem Standardisasi Nasional di Bidang Pertanian, ditindaklanjuti dengan peraturan untuk Persyaratan Dasar (Pre Requisite) Sistem Jaminan Mutu dan Keamanan Pangan seperti Permentan No.35/Permentan/ OT.140/7/2008 tentang Persyaratan Penerapan Cara Pengolahan Hasil Pertanian Asal Tumbuhan Yang Baik. Regulasi teknis tersebut merupakan Persyaratan Dasar (Pre Requisite) Jaminan Mutu dan Keamanan Pangan berdasarkan Sistem HACCP. Oleh karena itu diperlukan pedoman-pedoman yang akan digunakan sebagai acuan dalam rangka mengimplementasikan semua regulasi yang telah ditetapkan.

Bagi pelaku usaha skala kecil, Sistem Jaminan Mutu dan Keamanan Pangan dapat dilakukan secara bertahap yaitu dengan menerapkan persyaratan dasar (Pre Requisite) saja terlebih dahulu, seperti penerapan Cara Pengolahan yang Baik (CPB) atau GMP kemudian dilanjutkan dengan Sistem Mutu Keamanan Pangan berdasarkan sistem HACCP, yang akhirnya dapat menghasilkan produk yang aman dan bermutu. 
Tabel 1. Tingkat Pelaksanaan Komponen GMP PPKR Jembrana

\begin{tabular}{|c|c|c|c|}
\hline Persyaratan dan Penerapan GMP & $\%$ Pelaksanaan & Skor & Kriteria \\
\hline $\begin{array}{l}\text { 1. Prasarana dan Sarana } \\
\text { a. Lokasi }(100 \%) \\
\text { b. Bangunan }(76,7 \%) \\
\text { c. Fasilitas Sanitasi }(42,4 \%) \\
\text { d. Gudang }(50 \%) \\
\text { e. Mesin dan Peralatan }(38,9 \%) \\
\text { f. Pemeliharaan Bangunan dan Sarana } \\
\text { Kerja }(51,7 \%) \\
\end{array}$ & 59,9 & 3 & Sebagian \\
\hline $\begin{array}{l}\text { 2. Proses Produksi } \\
\text { a. Penyiapan Bahan }(88,3 \%) \\
\text { b. Proses Pengolahan }(56 \%) \\
\text { c. Pengemasan }(31,3 \%) \\
\text { d. Pelabelan }(56,7 \%) \\
\end{array}$ & 58,1 & 4 & Agak tinggi \\
\hline 3. Penyimpanan & 45,5 & 3 & Sebagian \\
\hline $\begin{array}{l}\text { 4. Keamanan dan Keselamatan Kerja serta Pen- } \\
\text { gelolaan Lingkungan } \\
\text { a. Keamanan dan Keselamatan Kerja }(33,3 \%) \\
\text { b. Pengelolaan Lingkungan }(11,1 \%)\end{array}$ & 22,2 & 2 & Agak rendah \\
\hline $\begin{array}{l}\text { 5. Kesehatan dan Kebersihan Pekerja } \\
\text { a. Kesehatan Pekerja ( } 25 \%) \\
\text { b. Kebersihan Pekerja (44\%) } \\
\end{array}$ & 34,5 & 2 & Agak rendah \\
\hline 6. Pemeliharaan & 28,6 & 2 & Agak rendah \\
\hline $\begin{array}{l}\text { 7. Pengawasan, Pencatatan, dan Penelusuran } \\
\text { Balik } \\
\text { a. Sistem Pengawasan dan Pencatatan } \\
\text { b. Penelusuran Balik }\end{array}$ & 80 & 5 & Tinggi \\
\hline
\end{tabular}

\section{Hasil Evaluasi Pelaksanaan GMP}

Tingkat pelaksanaan GMP di PPKR Jembrana secara keseluruhan adalah sebesar 47,0\% (kategori 3) atau dengan kata lain tingkat pelaksanaan komponen GMP di PPKR Jembrana masih sebagian. Tingkat pelaksanaan komponen GMP di PPKR Jembrana tersaji di Tabel 1.

Tabel tersebut menunjukkan persen dan skor tingkat pelaksanaan GMP di PPKR Jembrana berdasarkan tiap komponennya. Tingkat pelaksanaan komponen GMP yang sudah tergolong kategori tinggi adalah komponen Pengawasan, Pencatatan, dan Penelusuran Balik yaitu sebesar $80 \%$. Nilai pelaksanaan komponen yang tinggi dapat memudahkan PPKR Jembrana untuk mengajukan sertifikasi GMP kepada Pejabat Fungsional Pengawas Mutu Hasil Pertanian (PMHP) pada Lembaga Pengawas Mutu dan Keamanan Pangan Hasil Pertanian yang disebut sebagai Otoritas Kompeten Keamanan Pangan Pusat ataupun Daerah (OKKP-P/OKKP-D). Disisi lain, 3 komponen GMP masih tergolong tingkat pelaksanaan agak rendah, diantaranya komponen Keamanan dan Keselamatan Kerja $(22,2 \%)$, Kesehatan dan Kebersihan Pekerja $(34,5 \%)$, serta komponen Pemeliharaan $(28,6 \%)$.

\section{Prasarana dan Sarana}

Komponen prasarana dan sarana yang harus segera diperbaiki adalah fasilitas sanitasi dan mesin dan peralatan, sebab kedua sub komponen ini nilai persentasenya paling rendah dibandingkan sub komponen lain. Permentan No.35/Permentan/OT.140-/7/2008 mensyaratkan fasilitas sanitasi melalui 6 parameter, diantaranya sarana air bersih, fasilitas pencucian, sarana pembuangan, sarana toilet, peringatan-peringatan kebersihan/saniter, dan tersedianya sarana lain.

Meskipun tersedia fasilitas pencucian di ruang pengolahan, namun fasilitas pencucian yang ada tidak memenuhi persyaratan GMP bahwa fasilitas pencucian bahan baku dan peralatan harus dilengkapi dengan air panas (khususnya untuk pencucian dan sanitasi peralatan) dengan daya semprot yang memadai (tekanan $15 \mathrm{psi}=1,2$ $\mathrm{kg} / \mathrm{cm}^{2}$ ). Untuk parameter saluran pembuangan, 
PPKR Jembrana belum memenuhi persyaratan pengolahan pembuangan dan saluran pembuangan untuk buangan terolah. Tempat cuci tangan perlu dilengkapi dengan deterjen dan handuk. Selain itu diperlukan peringatan-peringatan kebersihan/saniter.

Pada sub komponen mesin dan peralatan, PPKR Jembrana hanya memenuhi persyaratan GMP 38,9\%. Tata letak mesin seharusnya diatur sesuai dengan proses yang mengalir dengan lancar, sejak bahan masuk, proses, pengemasan, pengepakan, penyimpanan sampai produk siap didistribusikan/dipasarkan, sehingga dapat meminimalkan terjadinya cross contamination. Selain itu beberapa alat masih berpeluang menimbulkan kontaminasi pada produk sebab beberapa alat tidak dibersihkan (Gambar 2). Sisa-sisa bahan yang menempel tersebut bisa terkontaminasi jamur dan khamir dan akan mengkontaminasi bahan baru yang diproses.

PPKR Jembrana sebaiknya lebih memperhatikan upaya pembersihan dan sanitasi pabrik secara menyeluruh. Proses pembersihan dan sanitasi terkait erat dengan kualitas keamanan pangan yang dihasilkan. Dalam hal keamanan pangan OKKP-D sangat ketat terhadap kemungkinan terjadinya bahaya-bahaya kontaminasi yang berpengaruh terhadap keamanan pangan, baik berupa penyimpangan minor, mayor, serius, maupun kritis.

Pasta dan lemak kakao bisa dikategorikan sebagai produk yang memiliki high water activities ( $\mathrm{a}_{\mathrm{w}}$ tinggi) sehingga sangat rentan terhadap serangan mikroorganisme, apalagi dengan kehadiran susu sangat rentan terhadap serangan bakteri Salmonella. Dikarenakan agresivitasnya, Salmonella termasuk bakteri yang sangat berbahaya dalam dosis infeksi yang sangat rendah. Standar keberadaan Salmonella dalam produk kakao adalah tidak terdeteksi dalam $25 \mathrm{~g}$ sampel. Sementara itu, bakteri enteropatogenik mengkontaminasi dan mampu bertahan hidup sejak proses pasca panen. Tangan pekerja, alat dan tanah yang tercemar adalah sumber utama penyebaran bakteri ini di produk kakao (Rahmadi, 2009).

\section{Proses Produksi}

PPKR Jembrana telah melaksanakan komponen proses produksi sebesar 58,1\% terdiri dari 4 sub komponen yaitu penyiapan bahan, proses pengolahan, pengemasan, dan pelabelan. Nilai sub komponen yang paling rendah adalah pengemasan, yaitu sebesar 31,3\%. Pemilihan jenis pengemas belum mempertimbangkan daya lindung terhadap uap air dan gas barrier serta daya lindung terhadap sinar matahari, ini perlu diperbaiki sebab sangat menentukan mutu produk. Hal lain yang perlu diperbaiki adalah pemilihan pengemas perlu disesuaikan dengan harga. Jika harga pengemas terlalu tinggi, maka akan semakin meningkatkan harga jual produk. Jika harga jual terlalu tinggi meskipun kualitas produk sama dengan produk-produk yang ada dipasaran, daya saingnya akan lebih rendah.

\section{Penyimpanan}

Prosedur penyimpanan yang tidak baik dapat mengakibatkan kontaminasi produk hingga kerusakan dan tidak aman untuk dikonsumsi. Ruang penyimpanan bahan baku, bahan tambahan, dan bahan penolong PPKR Jembrana terletak di Bangunan Pengolahan II. Dalam prakteknya ruang penyimpanan merupakan ruangan multi fungsi, selain digunakan sebagai tempat penyimpanan, ruang ini juga berfungsi sebagai tempat dilakukannya proses tempering coklat dan proses pengemasan. Bahkan ruangan tersebut digunakan sebagai ruang display produk-produk jadi yang ditunjukkan kepada para tamu dan calon pembeli. Dalam persyaratan GMP harusnya pemakaian ruang multi proses ini dihindarkan, karena berpeluang terjadinya kontaminasi silang yang berasal dari calon pembeli/para tamu yang tidak steril seperti yang terlihat pada.

Produk jadi yang belum dikemas sebaiknya ditempatkan terpisah di tempat lain. Meskipun penyimpanan dilakukan menggunakan prinsip FIFO (first in first out), namun pada prakteknya sulit dilakukan mengingat tidak ada pemisahan antara produk baru dan produk lama. Hal ini dikarenakan belum ada kode produksi yang tercantum pada pengemas mengenai kapan produksi dilakukan.

\section{Keamanan dan Keselamatan Kerja serta Penge- lolaan Lingkungan}

Komponen ini terdiri dari dua sub komponen, yaitu keamanan dan keselamatan kerja, dan yang ke dua adalah pengelolaan lingkungan. Sub komponen keamanan dan keselamatan kerja hanya dilaksanakan 22,2\%. PPKR Jembrana seharusnya melengkapi pekerjanya dengan masker dan penutup kepala. Masker dan penutup kepala dapat meminimalkan terjadinya kontaminasi produk oleh pekerja. Pemakaian masker dan pe- 
nutup kepala merupakan tindakan sanitasi yang wajib dipenuhi oleh unit pengolahan.

Sub komponen ke dua adalah pengelolaan lingkungan. Pada sub komponen ini PPKR Jembrana selain tidak melakukan pengelolaan terhadap limbah padat, cair, gas, asap, ataupun debu, PPKR Jembrana juga tidak melakukan pengendalian gangguan bunyi lalu lintas transportasi (bangunan tidak dilengkapi peredam bunyi meskipun terletak di jalan provinsi), uap panas, pencemaran udara, dan gangguan lainnya.

\section{Kesehatan dan Kebersihan Pekerja}

Komponen GMP kesehatan dan kebersihan pekerja kurang diperhatikan oleh PPKR Jembrana, hal ini terlihat masih rendahnya tingkat pelaksanaan persyaratan GMP pada komponen ini, yaitu sebesar $34,5 \%$. Sebagai persyaratan GMP, seharusnya dilakukan pemeriksaan kesehatan karyawan secara berkala setiap 1 (satu) tahun sekali. Peraturan mengenai hygiene karyawan seharusnya tertulis, sehingga akan mempermudah proses pengawasan hygiene karyawan. Karyawan yang melakukan penanganan makanan seharusnya diwajibkan mengenakan pakaian kerja khusus yang bersih, memakai penutup rambut yang efektif diseluruh areal pengolahan, mengenakan masker penutup mulut dan hidung yang efektif di seluruh areal pengolahan dan tidak memakai perhiasan tangan. PPKR Jembrana sebaiknya melakukan tindakan koreksi untuk peryaratan GMP pada komponen kesehatan dan kebersihan pekerja sebab akan mempengaruhi mutu dan keamanan pangan yang dihasilkan

\section{Pemeliharaan}

Pemeliharaan segala fasilitas produksi akan menghasilkan mutu produk yang baik. Pemeliharaan juga akan meminimalkan penggunaan biaya akibat kerusakan yang lebih parah. Pemeliharaan bangunan dapat dilakukan dengan jalan pembersihan dan disinfeksi. Pemeliharaan bangunan akan kurang efektif jika tidak dilakukan secara periodik dan terjadwal.

Pemeliharaan juga terkait dengan pemeliharaan terhadap alat dan perlengkapan. Alat perlengkapan yang ada seharusnya selalu dibersihkan dan didisenfeksi dengan baik sedemikian rupa sehingga tingkat kontaminasi rendah atau sama sekali tidak ada, sehingga kualitas keamanan pangan terjamin. Hal yang perlu diperhatikan adalah perlunya melakukan kalibrasi alat secara periodik. Misalnya kalibrasi alat moisture test (alat pengukur kadar air) sangat penting untuk mengetahui kadar air bahan baku berupa biji kakao, yang kemudian akan menentukan besarnya suhu sangrai yang akan digunakan. Jika alat tersebut eror atau tidak akurat, mutu coklat yang dihasilkan akan berkurang.

\section{Pengawasan Pencatatan dan Penelusuran Balik}

Komponen terakhir dari GMP adalah pengawasan, pencatatan, dan penelusuran balik. Tindakan-tindakan ini berkaitan erat dengan meminimalkan kegiatan/prosedur yang tidak efisien yang akan menimbulkan biaya yang juga tidak efisien. Persyaratan GMP pada komponen ini yang belum dipenuhi oleh PPKR Jembrana adalah hasil pengawasan tidak didokumentasikan, dicatat, dan disimpan dengan baik untuk menunjukkan bukti bahwa aktifitas produksi sudah sesuai dengan ketentuan. Catatan mengenai kegiatan /upaya-upaya rutin yang dilakukan dalam rangka pengendalian lingkungan dan upaya-upaya lain yang bersifat kasus seharusnya juga didokumentasikan. Hal ini diperlukan agar PPKR Jembrana tidak mengulang kesalahan yang sama di kemudian hari, sebab jika demikian akan meningkatkan penggunaan biaya, dan tidak efisien.

\section{Hasil Analisis Efisiensi}

Efisiensi biaya produksi di PPKR Jembrana menggunakan pendekatan $\mathrm{R} / \mathrm{C}$ ratio atau dikenal sebagai perbandingan (nisbah) antara penerimaan dan biaya. Upaya yang bisa dilakukan untuk meningkatkan efisiensi penggunaan biaya adalah dengan meningkatkan penerimaan dan menekan penggunaan biaya yang dikeluarkan. Efisiensi penggunaan biaya produksi PPKR Jembrana dapat dilihat pada Tabel 2.

Tabel 2. Efisiensi Penggunaan Biaya Produksi PPKR Jembrana

\begin{tabular}{ll}
\hline \multicolumn{1}{c}{ Uraian } & \multicolumn{1}{c}{ Nilai } \\
\hline Total Penerimaan (TR) & $\mathrm{Rp} 23.867 .650$ \\
Total Biaya Produksi (TC) & $\mathrm{Rp} 19.580 .400$ \\
R/C Ratio & 1,22 \\
\hline
\end{tabular}

Penerimaan PPKR Jembrana berasal dari penjualan produk-produk yang dihasilkan, antara lain permen coklat kemasan kotak, permen coklat batang kecil, permen coklat batang besar, permen coklat, cookies, coklat 3 in1, bubuk, lemak, dan biji kakao. Biaya produksi PPKR Jembrana meliputi beberapa komponen, diantaranya 
biaya produksi, biaya pemasaran, biaya administrasi dan umum, serta biaya lain. Penggunaan biaya terbesar adalah pada biaya produksi, yaitu sebesar $98,9 \%$.

Tabel 3. disajikan struktur biaya PPKR Jembrana selama 1 tahun produksi.

\begin{tabular}{|c|c|c|}
\hline Komponen Biaya & Total Biaya & Persen \\
\hline 1.Biaya Produksi & Rp. $\quad 273.157 .168$ & $98,9 \%$ \\
\hline $\begin{array}{l}\text { a. Biaya Bahan } \\
\text { Baku Langsung }\end{array}$ & 19.928 .525 & \\
\hline $\begin{array}{l}\text { b.Biaya Tenaga } \\
\text { Kerja Langsung }\end{array}$ & 32.400 .000 & \\
\hline $\begin{array}{l}\text { c. Biaya Overhead } \\
\text { Pabrik }\end{array}$ & Rp. 220.828 .643 & \\
\hline $\begin{array}{l}\text { 2. Biaya Pemasa- } \\
\text { ran }\end{array}$ & 1.586 .800 & $0,6 \%$ \\
\hline $\begin{array}{l}\text { 3. Biaya Adminis- } \\
\text { trasi dan Umum }\end{array}$ & 36.200 & $0,3 \%$ \\
\hline 4.Biaya Lain & 82.600 & $0,2 \%$ \\
\hline Total Biaya & Rp. $\quad 276.162 .768$ & $100,0 \%$ \\
\hline
\end{tabular}

Dari perhitungan $\mathrm{R} / \mathrm{C}$ yang telah dilakukan dalam 1 tahun produksi, dapat diketahui bahwa nilai perbandingan antara penerimaan dan biaya adalah sebesar 1,22. Secara teoritis dengan nilai $\mathrm{R} / \mathrm{C}$ lebih dari 1 , PPKR Jembrana bisa dikatakan telah efisien dalam penggunaan biaya. Nilai R/C sebesar 1,22 dapat diartikan bahwa dengan penggunaan biaya produksi sebesar Rp. 1.000,00 PPKR Jembrana akan memperoleh penerimaan sebesar Rp. 1.220,00. Hal ini menunjukkan bahwa PPKR Jembrana telah mampu mengalokasikan biaya produksinya secara efisien.

Yang perlu dijadikan catatan adalah bahwa nilai tersebut dihasilkan dengan struktur biaya bersubsidi. Beberapa biaya disubsidi oleh Pemerintah Kabupaten Jembrana. Biaya-biaya yang dimaksud antara lain biaya bahan baku utama (biji kakao), gaji karyawan, penyusutan alat, penyusutan mesin, penyusutan bangunan, pajak bumi dan bangunan, biaya listrik, dan biaya air. Beberapa simulasi dapat dilakukan dengan meniadakan subsidi biaya.
Tabel 3. Nilai R/C Simulasi

\begin{tabular}{lr}
\hline \multicolumn{1}{c}{ Simulasi R/C } & Nilai R/C \\
\hline 1. Bersubsidi Bk,Gj,Pa,Pm,Pb,PB- & 1,22 \\
B,L,A & \\
2. Bersubsidi + tanpa retur dan gagal & 1,43 \\
produksi & \\
3. Non Subsidi Biji Kakao & 0,66 \\
4. Non Subsidi Gaji & 0,46 \\
5. Non Subsidi Penyusutan Alat & 1,20 \\
6. Non Subsidi Penyusutan Mesin & 0,18 \\
7. Non Subsidi Penyusutan Bangunan & 0,25 \\
8. Non Subsidi PBB & 1,21 \\
9. Non Subsidi Listrik & 0,62 \\
10. Non Subsidi Air & 1,14 \\
11. Real (Tanpa Subsidi) & 0,09 \\
\hline
\end{tabular}

Simulasi peniadaan subsidi biaya dapat dilihat pada tabel 3. Jika dilakukan simulasi dimana subsidi bahan baku biji kakao dihapuskan, maka $\mathrm{R} / \mathrm{C}$ ratio menjadi 0,66 atau berkurang sebesar $46,18 \%$ dari nilai R/C ketika biaya tersebut disubsidi. Nilai penurunan efisiensi terbesar adalah saat subsidi penyusutan mesin dilakukan, yaitu berkurang hingga $85,13 \%$ dari nilai $\mathrm{R} / \mathrm{C} 1,22$ menjadi hanya 0,18 . Tingginya nilai investasi alat menyebabkan juga tingginya biaya penyusutan tiap tahunnya, sehingga hal ini berpengaruh pada nilai efisiensi yang semakin menurun. Dengan adanya simulasi di atas dapat dikatakan bahwa peniadaan subsidi penyusutan alat, subsidi biaya air atau pajak bumi bangunan masih dapat diimbangi oleh besarnya nilai penerimaan PPKR Jembrana, sehingga nilai efisiensi masih lebih besar dari 1, atau dengan kata lain penggunaan biaya produksi masih efisien. Namun demikian ternyata, jika subsidi atas biji kakao/gaji/ penyusutan mesin/penyusutan bangunan/PBB/biaya listrik, nilai efisiensi menjadi turun hingga dibawah nilai 1 , artinya penggunaan biaya tidak lagi efisien. Apalagi jika keseluruhan subsidi tersebut dihapuskan, maka nilai efisiensi menjadi hanya 0,09 . Ini berarti sebetulnya penggunaan biaya di PPKR Jembrana tidak efisien bahkan rugi. Sebab besarnya penggunaan biaya lebih tinggi dibandingkan penerimaan.

Dalam kajian peneliti, PPKR Jembrana belum melaksanakan manajemen mutu proses (GMP) secara menyeluruh. Sebagai contoh, sub komponen yang belum dilakukan sesuai standar GMP adalah prosedur pengolahan yang belum memperhatikan suhu dan waktu pengovenan sehingga dihasilkan produk gosong (cacat produk). Dengan munculnya cacat produk berarti memunculkan tambahan quality costs berupa 
process failure costs $(\mathrm{Rp} 112.750,00)$ yang semestinya bisa dihindari jika PPKR Jembrana menerapkan GMP. Selain itu adanya retur juga memunculkan quality cost tambahan berupa product return cost (sebesar Rp 2.733.500,00). Retur tersebut disebabkan tidak laku jual karena produk mengalami cacat selama penjualan. Ini berarti mutu produk yang dihasilkan tidak konsisten (inkonsistensi mutu). Inkonsistensi mutu menunjukkan bahwa GMP belum dilaksanakan dengan baik. Tidak adanya manajemen yang secara khusus menangani GMP merupakan salah satu faktor adanya inkonsistensi mutu. atau juga dikarenakan produk yang dijual tersebut tidak sesuai spesifikasi konsumen dari segi rasa, estetika, dan harga.

Quality costs tambahan dinilai tidak efisien sebab berasal dari prosedur yang tidak dilakukan secara efisien (sesuai standar), terlebih kondisi ini berulang tanpa ada tindakan koreksi atau perbaikan. Dari struktur biaya dapat diketahui bahwa process failure costs terjadi berulang, tidak hanya dalam 1 bulan produksi. Munculnya biaya tambahan yang tidak efisien dapat dikurangi dengan menerapkan GMP.

Pengurangan biaya yang tidak efisien dapat meningkatkan efisiensi penggunaan biaya yang dilihat dari nilai R/C. Seperti contoh pada munculnya quality costs tambahan di atas, adalah karena tidak dilakukannya prosedur pengolahan sesuai standar GMP. Jika diasumsikan GMP telah diterapkan menyeluruh, biaya tersebut tidak akan muncul. Dengan demikian jika dilakukan simulasi process failure costs dan product return costs tidak ada, maka efisiensi penggunaan biaya $(\mathrm{R} / \mathrm{C})$ akan meningkat dari 1,22 menjadi 1,43 (meningkat sebesar 17,01\% dari nilai efisiensi awal. Hal ini sejalan dengan kajian Dianameci (2007), bahwa munculnya biaya tidak efisien yang berasal dari pekerjaan tidak efisien dapat diatasi dengan penerapan manajemen mutu. GMP dapat dijadikan sebagai langkah awal untuk mengurangi pekerjaan tidak efisien. Dengan mengurangi biaya yang tidak efisien, maka efisiensi meningkat dan keuntungan yang diperoleh semakin besar.

\section{KESIMPULAN}

Tingkat pelaksanaan GMP berdasarkan Permentan No.35/Permentan/-OT.140/7/2008 di PPKR Jembrana adalah sebesar 47\% (kategori 3) atau dengan kata lain tingkat pelaksanaan komponen dan subkomponen GMP di PPKR
Jembrana masih sebagian. Pelaksanaan GMP tersebut disusun oleh komponen (1) Prasarana dan Sarana 59,9\%, (2) Proses Produksi 58,1\%, (3) Penyimpanan 45,5\%, (4) Keamanan dan Keselamatan Kerja serta Pengelolaan Lingkungan $22,2 \%$, (5) Kesehatan dan Kebersihan Pekerja 34,5\%, (6) Pemeliharaan 28,6\%, (7) Pengawasan, Pencatatan, dan Penelusuran Balik 80\%.

Dalam 1 tahun produksi, penggunaan biaya PPKR Jembrana efisien ditunjukkan dengan nilai $\mathrm{R} / \mathrm{C}>1$, namun nilai tersebut dihasilkan dengan struktur biaya bersubsidi (biaya bahan baku/biji kakao, gaji karyawan, penyusutan alat, penyusutan mesin, penyusutan bangunan, pajak bumi dan bangunan, biaya listrik, dan biaya air). Jika subsidi dihapuskan, maka nilai efisiensi menjadi turun, bahkan menjadi tidak efisien. PPKR Jembrana sebaiknya menerapkan GMP secara menyeluruh, dengan demikian biaya yang tidak efisien berupa process failure cost dan product return cost dapat dikurangi, sehingga efisiensi penggunaan biaya meningkat dan keuntungan yang diperoleh semakin besar.

PPKR Jembrana perlu dukungan pemerintah, dalam hal ini Dinas Perindustrian Kabupaten Jembrana, berupa upaya perbaikan dan koreksi agar persyaratan GMP dapat diterapkan secara menyeluruh sehingga terjadi peningkatan efisiensi. Utamanya komponen-komponen yang tingkat pelaksanaannya ma sih kategori 2 (agak rendah) seperti komponen Keamanan dan Keselamatan Kerja serta Pengelolaan Lingkungan, komponen Kesehatan dan Kebersihan Pekerja, dan juga komponen Pemeliharaan. Jika semua komponen GMP telah diterapkan secara menyeluruh, PPKR Jembrana dapat mengajukan sertifikasi GMP kepada Pejabat Fungsional Pengawas Mutu Hasil Pertanian (PMHP) pada Lembaga Pengawas Mutu dan Keamanan Pangan Hasil Pertanian.

\section{DAFTAR PUSTAKA}

Asheri, Vitalia Putri. 2014. Analisis Nilai Tambah Cokelat Batangan (Chocolate Bar) Di Pipiltin Cocoa, Kebayoran Baru, Jakarta Selatan. Bogor: Departemen Agribisnis Fakultas Ekonomi Dan Manajemen Institut Pertanian Bogor

Burhanuddin, K. Mudikdjo dan Asari. 2002. Implementasi Quality Function Development Dalam Peningkatan Manajemen Mutu. Jurnal Media Peternakan 25 (2): 64-69 
Davit, John, Ria Puspa Yusuf, dan Dewa Ayu Sri Yudari. 2013. Pengaruh Cara Pengolahan Kakao Fermentasi Dan Non Fermentasi Terhadap Kualitas, Harga Jual Produk Pada Unit Usaha Produktif (UUP) Tunjung Sari, Kabupaten Tabanan. E-Jurnal Agribisnis Dan Agrowisata, 2 ( 4): 191201

Dianameci, R. A. 2007. An Overview of Integrated Models for Quality Management in The Agri-Food Industry Trough Cost/ Benefit Analysis. Jurnal Standarisasi, 9 (3): $87-93$

Hasibuan, Abdul Muis, Rita Nurmalina dan Agus Wahyudi. 2012. Analisis Kebijakan Pengembangan Industri Hilir Kakao (Suatu Pendekatan Sistem Dinamis). Informatika Pertanian, 21 (2): $59-67$

ICCO. 2016. The World Cocoa Eeconomy: Past and Present. London: ICCO

Rahmadi, A. 2009. Food Review: Safety of Cocoa Products. [serial on line]. http://www.foodreview.biz/preview. php?view2\&id=55838. Diakses 25 Juni 2016

Rahmanu, R. 2009. Analisis Daya Saing Industri Pengolahan dan Hasil Olahan Kakao Indonesia. Bogor: Departemen Agribisnis Fakultas Ekonomi Dan Manajemen Institut Pertanian Bogor

Setiawati, Rini Marlina, M.H. Bintoro Djoefrie, dan Hartrisari Hardjomidjojo. 2007. Penentuan Produk Unggulan Berbasis Kakao Sebagai Alternatif untuk Meningkatkan Pendapatan Industri Kecil Menengah. Jurnal MPI, 2 (1): 58-69

Soekartawi. 1995. Teori Ekonomi Produksi. Jakarta: Rajawali Press

Suryaningsih, Ika Barokah. 2006. Strategi peningkatan mutu manajemen untuk pengembangan industri kecil di Kabupaten Jember. Jurnal Manajemen Akuntansi dan Bisnis, 4 (3) 